\title{
Adaptation to New Habits: School-Based Financing Strategies for Public High School During the Covid- 19 Pandemic
}

\author{
Gema Muhammad Shidiq*, Endang Herawan \\ School of Postgraduate \\ Universitas Pendidikan Indonesia \\ Bandung, Indonesia \\ *yakuzatai.gm@gmail.com
}

\begin{abstract}
This research has purposed to provide an overview of high school's funding strategies in facing the New Normal during the Covid-19 pandemic. The qualitative method was used through survey questionnaire with a number of school principals in several high schools in West Java Province with the Snowball sampling technique. Observation techniques and documentation of education funding in the schools were also implemented. The results showed that every high school needs to change the education funding strategy based on school needs during the Covid-19 pandemic using the School-Based Budgeting (SBB) approach; implementing budget efficiency and optimizing education funding from the community. It can be concluded that in Covid-19 pandemic, along with New Normal implementation, the education funding using the SBB approach could allow schools to adjust their needs during the Covid-19 pandemic.
\end{abstract}

Keywords-covid-19, education funding, high schools, new normal, school-based budgeting, West Java Province

\section{INTRODUCTION}

\section{A. Background}

The Covid-19 pandemic gives a significant impact on various sectors of life, one of them is education. On January 30, 2020, WHO has determined it as Kedaruratan Kesehatan Masyarakat yang Meresahkan Dunia/ Public Health Emergency of International Concern (KKMMD / PHEIC). The increase in the number of COVID-19 cases is progressing fast enough and there has been a spread between countries [1].

In terms of education, UNICEF found that more than 120 countries have implemented social distancing through school closures, affecting 1.6 billion students worldwide [2].

In respond to this, an effort is needed to keep education services in schools running. In this case, education financing is one of the cores to make it possible. According to Green, in order to restore the function and roles of the schools, the government should provide increase in school funding. Congress/ Council should allocate significant funding to support public schools at least for the next two years; these allocations should include strong supports for high-needs districts in particular [3].

In Indonesia, this was implemented from early March by closing schools which had an impact on the learning process that was done from home and cancelled the implementation of the 2020 National Examination [4]. This is not entirely smooth sailing, although nearly 47 million households (66 percent) have access to the internet, online, distance learning presents a challenge (BPS, Indonesia, Welfare Statistics, 2019). Online learning is a new thing to many students and teachers. Besides being online, it is also important to explore alternatives of offline learning to provide opportunities for all children to continue learning, including those who do not have access to the internet [5].

West Java Province itself, as a province with the largest population in Indonesia with an area of $35,377.76 \mathrm{~km} 2$, has a population of 48.68 million people. This population is spread across 18 regencies, 9 municipalities, 627 districts, 645 urban villages and 5,312 villages [6], in preventing the spread of Covid-19, the Governor of West Java as of March 19, 2020 determined the Status of Certain Conditions Emergency Disaster Outbreak Due to Covid-19 [7]. Seeing the condition of West Java as the province with the largest population in Indonesia, the implementation of the strategy for handling the impact of Covid-19 in West Java, especially its impact on education, is expected to be an overview for other Provinces in handling the impact of the Covid-19 pandemic.

The implementation of education services, especially education funding in West Java at Public Senior High School and Vocational School is interesting to be researched, due to changes in fundamental policies at Public Senior High School and Vocational School in West Java for the 2020/2021 school year, namely the absence of monthly tuition fees by state schools, or in other words, the Regional Government of West Java Province fully finances the monthly fee for Public Senior High School and Vocational School [8]. 


\section{B. Aim of Research}

Aligned with the background, it is important to understand the condition of education services in West Java during the Covid-19 pandemic, as well as the strategy of middle schools in West Java at managing education funding, especially so that education services in schools could keep going according to the plan that has been prepared. Especially for Public Senior High School and Vocational School, where it is no longer allowed to collect money from the parents of students.

\section{Paper Structure}

This paper is organized into several sections. The first part is an introduction, containing the background of the research, the aim of research, and the structure of the paper. The next section is a literature review which contain theory about education financing and budgeting, followed by the third section, which is a research method. Fourth section is research results. The fifth part is discussion, and followed by the last section which is conclusion and recommendation.

\section{LITERATURE REVIEW}

Education Financing in Indonesia cannot be separated from Law No.20 of 2003 [9] concerning the National Education System. In terms of education financing, it is regulated in Chapter XIII of Education Funding, Responsibility for Funding, Article 46 paragraphs (1) and (2), namely: (1) Education funding is the joint responsibility of the Government, Local Government, and the community, and (2) The Government and Regional Governments are responsible for providing the education budget as stipulated in Article 31 paragraph (4) of the 1945 Constitution.

From this regulation, it can be interpreted that education financing requires synergy from both the Government, Local Government, and the Community. Every stakeholder needs to contribute in terms of financing education for each education unit.

The source of education funding itself, empirically, the education unit in Indonesia refers to Government Regulation number 48 of 2008 [10] concerning Education Funding. In Chapter V Education Funding Resources, Article 51 can be described as follows

1. Local government education funds can be sourced from:
a. the government budget;
b. local government budget;
c. non-binding foreign party assistance; and / or
d. other legitimate sources.

2. Educational funds for education providers or education units established by the community may come from:

a. founder of an educational provider or unit established by the community;

b. assistance from the community, outside students or their parents / guardians;

c. Government assistance;

d. local government assistance; e. non-binding foreign party assistance;

f. the results of the business of the education provider or unit; and / or

g. other legitimate sources.

3. Education funds for educational units administered by the Government may come from:

a. the government budget;

b. local government assistance;

c. levies from students or their parents / guardians which are implemented in accordance with statutory regulations;

d. assistance from educational unit stakeholders outside students or their parents / guardians;

e. assistance from non-binding foreign parties; and / or

f. other legitimate sources.

4. Education funds for education units organized by local governments may come from:
a. local government assistance;
b. Government assistance;
c. levies from students or their parents / guardians which are implemented in accordance with statutory regulations;
d. assistance from educational unit stakeholders outside students or their parents / guardians;
e. assistance from foreign parties that are not binding; and / or
f. other legitimate sources.

5. Education funds for educational units organized by providers or educational units established by the community may come from:
a. assistance from the organizers or the education unit concerned;
b. assistance from the Government;
c. assistance from local governments;
d. levies from students or their parents / guardians which are implemented in accordance with statutory regulations;
e. assistance from educational unit stakeholders outside students or their parents / guardians;
f. non-binding foreign party assistance; and / or
g. other legitimate sources.

When viewed from the standards as mentioned above, the Government has rolled out various policies in meeting education funding, based on the 2018 State Budget information released by the Ministry of Finance [11] In terms of revenue, the Government in 2018 implemented policies including:

1. Optimization in the field of taxation in 2018 was sharpened by the issuance of legislation related to open access and information to financial data

2. Optimizing state income while maintaining the investment climate

3. Optimizing state revenue with realistic tax revenue targets based on the latest data base 
Meanwhile, in carrying out spending, the Government has policies including:

1. Shifting consumptive spending into productive spending in the context of accelerating economic growth and accelerating the realization of state spending;

2. Efficiency of spending and increase in productive spending to support priority programs;

3. Continue to strengthen the quality of state spending and remain consistent in making efficient non-priority spending without reducing the achievement of the planned output targets.

Education is one of the priority expenditures, in this case education gets a proportion of $20 \%$ of the total funding comes from the State Budget, which amounts to 2,220.7 trillion Rupiah. The total education budget is 444.2 trillion rupiahs, with details of 149.7 trillion rupiah managed by the ministry, 279.5 trillion rupiah transferred by regions, and related to the financing of 15 trillion rupiahs.

Whereas in the regions, especially in West Java, the total budget for the 2018 Fiscal Year amounted to 33 trillion Rupiah, funding for education totaled 6 trillion Rupiah which was divided into the management of the Education Office amounting to 2 Trillion Rupiah and Funding for Teachers and Education Personnel (Salaries and Employee Benefits) in the amount of 4 trillion Rupiah.

From these two sources, it can be concluded that the Government and Regional Governments in general have prioritized education financing with various policies that refer to the most prioritized needs.

The financial standard is a standard that regulates the components and the amount of operational cost for an educational unit which is valid for one year and consists of investment costs, operational costs, and personal costs [12]. In this case, the government has made such an effort to improve the quality of education, for example through funding in the form of School Operational Assistance Funds (BOS), Regional School Operational Assistance (BOSDA), Educational Operational Assistance (BOP), Special Allocation Funds (DAK), and so on. Various regulations and policies have also been made in such a way as to increase the accessibility and quality of education.

The cost of education unit consists of investment costs (educational land and other than educational land), operating costs (personnel and non-personnel), tuition assistance, and scholarships [10]. The main source of costs for education units at the Public Senior High School and Vocational School comes from the Government and Local Government. In this case, according to Levin, the government has policies and regulations related to the funding of school education. School funding is the process where the income and available resources are used to formulate and operationalize schools in different geographic areas and different levels of education [13].

With the provision of assistance such as school operational assistance funds from the government or local governments and voluntary donations from the community, it is hoped that they will be able to fulfill the needs of schools. In fact, each school has different amounts of expenditure and students. The amount of aid and voluntary donations received could not guarantee that school needs are fulfilled.

Strategy is an overall approach that deals with the implementation, planning and execution of an activity within a certain period of time [14]. The funding strategy includes planning strategies (implementing ideas), implementation, evaluation, and follow-up. The planning strategy for education funding in Public Senior High School and Vocational School, begins with the formulation of the School's Vision and Mission, the planning strategy and preparation of the RAPBS are implemented through a simple SWOT analysis [13].

Funding strategies that can be applied to implement the educational process which is suitable for the students' learning needs, should be centered on the programs that become the object of costs, to achieve the effectivity and efficiency of education funding [15]. In this matter, the important factor is determination of the strategy by the school funding manager. One of key factors in educational development lies on the ability of human resources in managing available funds with reference to the basic needs and priority scale of educational development program from year to year [16].

\section{RESEARCH METHODS}

Descriptive analytics method was used in this study. The method was chosen in order to explain and interpret to obtain overview of a case which is focus on actual problems as they are at the time the research was conducted.

Data analysis techniques used in this study was qualitative approach. This design is used to understand \& interpret social phenomenon, especially about public school financing during covid-19 pandemic [17]

Distribution of survey questionnaire was chosen as research instruments in this research. In general, the questionnaire contains about the implementation of education services and the strategy of education funding management in each school during Covid-19 pandemic.

Snowball sampling was used as sampling technique, started from determination of 19 Regency/City in West Java, continued from the representation of Public Senior High School and Vocational School in each Regency/City, so as 45 respondents were selected that consist of Head Principal of Public Senior High School and Vocational School in West Java Province. 


\section{RESULTS}

Based on the research that was implemented, it can be found that the number of students has increased from $2019 / 2020$ school year to 2020/2021 school year for 35 out of 45 respondents from Public Senior High School and Vocational School. It means, the Covid-19 Pandemic had significant effect to the students' interests to enter state school.

In addition, $95 \%$ of schools already have a mid-term, annual work plan, or a plan which were embodied into activity and budget plans that is known as the School Revenue and Expenditure Budget Work Plan (RKAS). The remaining 5\% have a School Budget Work Plan but did not have a Medium Term Work Plan and an Annual Work Plan yet.

During the Covid-19 pandemic, it was found that all respondents did not open their schools, it means that the schools implemented the regulations to prevent the spread of Covid-19. On average, the implementation of educational services was implemented using online learning platform such as WhatsApp and Google Classroom. Virtual face-to-face applications such as Zoom Meetings and Cisco Webex were also used.

The budget sources obtained by schools on average came from the Central Government and Provincial Government, followed by 21 schools, including contributions from the parents of students. $80 \%$ of the respondents stated that education funding came from the Government / Regional Government which was not sufficient to fulfil school operational needs, meanwhile, related to the adequacy of funding for developing the quality of schools, $95 \%$ of them stated that the funding for education from the Government / Regional Government was insufficient.

As it is known that Public Senior High School and Vocational School in West Java Province has been funded through 2 main sources, which are School Operational Assistance (BOS) from the Ministry of Education, and Regional Education Operational Costs (BOPD/ Iuran Bulanan Gratis) from the Regional Government of West Java Province.

Both can be used by schools to meet operational costs and improve the quality of education. As for Public Senior High School and Vocational School in West Java, it is no longer possible to collect monthly fees to students because since the 2020/2021 school year, there has been a free monthly fee policy. To get around this, the average respondent (93\%) stated that contributions from students' parents were one of the main sources in fulfilling this matter. There are $2(4 \%)$ schools that think contribution from the surrounding community was the biggest contribution. 1 school $(2 \%)$ of them answered that the contribution from the Business World and the Industrial World gave the biggest contribution. The management of the donation, on average $(28 \%)$ involved all elements of the school, there are the Principal, Deputy Principal of the School, Head of Subdivision of School Administration, Teachers, School Administration Staff, School Committee, and Parents of Students.
The strategy undertaken by the schools in collecting these donations was through arranging a school work plan as mature and detailed as possible to be presented to all stakeholders who are the subject of donations including parents of students, business / industry, alumni, and the surrounding community.

During the Covid-19 pandemic, it was found that there were difficulties in collecting these donations due to difficulties in gathering large numbers of people, economic difficulties experienced by the parents of students, and parents of students who were not accustomed in using online modes, so that it was difficult to bring together the parents of students in online modes.

On average, respondents had solutions related to these problems, including the limitation of participant donors meeting, the donations were not fixed and could be paid in installments, as well as coordinating the implementation of donations with relevant stakeholders in the area around the school.
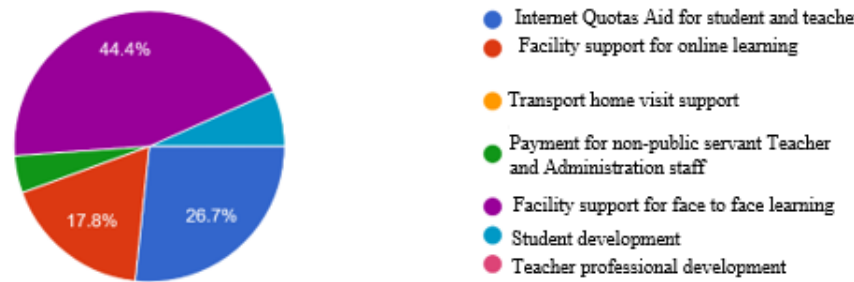

Fig. 1. Usage of donation.

As Figured by Figure.1, The donation that was obtained, $44 \%$ of them used the funds to prepare the infrastructure so that schools could conduct face-to-face meetings, $26 \%$ of them used the funds to provide quotas for teachers and students, and $17 \%$ used these funds to provide laptops / gadgets to support learning, others are used for the development of interests and talents of students and provision of salaries for non-civil servant teacher's / education personnel. On average, in its implementation, the monthly evaluation of funding management was held.

\section{DISCUSSION}

During the Covid-19 pandemic, there was budget efficiency in various funding sectors, with the aim to increase the budget for handling Covid-19 [18]. Even so, the efficiency of these funds should not interfere the services for children such as in education and social service sectors. The reprioritization of government budgets in response to a pandemic creates pressure to redirect funds towards new public health goals. Fiscal transfers to answer the needs at the regional level must be accompanied by clear technical guidance on child-responsive planning and utilization of funds [19].

A sharp decline in funding for public education could have long-term effects on student outcomes, adding the harmful impact of the crisis on the ability to support children's in the future. Debt cancellation or should be accompanied by 
conditions for increased social spending to avoid loss of human resources and the increase in poverty [20].

In the Covid-19 pandemic era like today, efficiency become the core in the implementation of education funding due to the shrinking resources and growing needs due to refocusing on handling Covid-19 [21]. This is also the case in Indonesia where there is an efficiency for both government and school budgets [22]. In increasing the efficiency of school spending, it is necessary to start by identifying regional goals and designing budgets so that all elements support these goals. By doing so, school leaders and local governments could analyze budgets to identify whether resource allocations support or even prevent the achievement of these goals, then take steps to reallocate them according to priority activities. There are following steps based on research and practice in setting goals before the implementation of budgets analysis [23]:

1. Build understanding of the school education community, including all stakeholders (staffs, parents, community members, and students). Conduct a selfexamination to identify and explain the community's beliefs, values, hopes, strengths, and priorities. Communicate with stakeholders at every step of the process.

2. Identify the needs, priorities, and goals of all students by examining sorted data on students' performance outcomes. Consider the environmental and contextual conditions of the school, or area. Build goals based on this data.

3. Ensure allocation of financial resources, grade the resources which are available, and align spending with objectives. Evaluate whether the resources are targeted for improvement in academic performance. Use the results to change the current allocation strategy.

\section{Continuously evaluating progress towards goals.}

Besides those steps, the flexibility in education funding in school is needed. One of them is through decentralization which is bigger in the usage of funds with School BasedBudgeting (SBB) approach. Chan stated that School-Based Budgeting is a decentralization of a school system's budgeting and spending functions, by devolving both responsibility and authority for these functions to school site agents. The goal of School-Based Budgeting is economic efficiency, i.e., to maximize the funds controlled by the school-site agent for school-level educational expenditures, not educational productivity. It cannot be assumed that School-Based Budgeting will be effective in every school system, and the proposed cost-benefit model should be applied to the particular facts and circumstances of a school system before adopting it [24].

Chan stated that in the implementation, the Head Principals, Teachers/Teacher groups, and school committees are the responsible parties. In Indonesia this is made possible by optimizing the role of school committees with the published of regulations by the Government through the Minister of Education and Culture Regulation number 75 of 2016 about School Committees [25].

The application of school-based management (SBM) as one of the implementations of the SBB is believed to be a model for implementing the proper education decentralization policy during the Covid-19 pandemic. Mulyasa argues that: School Based Management is a strategy to create an effective and productive school. This is because in the concept of SBM, decision making is placed in the closest position to learning, which is schools, although the minimum service standards are set by the government, schools are more flexible in managing resources, funding sources, learning resources and allocating them according to priority needs in school [26]

From the results of the research conducted, all respondents stated that the contribution of funds from the parents of students was one of the sources of funds that were able to help the funding that had been channeled from the government, there are School Operational Assistance from the Central Government and Regional Education Operational Costs from the Regional Government of West Java Province. Regional Education Operational Costs from the Regional Government of West Java Province is a new policy that eliminates monthly student fees [8]. In another meaning, schools are no longer allowed to collect fees for all students, it means another possible source of funds to finance educational services in schools is through donations.

The donations obtained are not coordinated from one point, it is government, but rather provide flexibility for schools to manage funding according to their needs [24]. The regulations that established during the Covid-19 pandemic also provide flexibility for schools, which one of them is managing School Operating Costs by providing flexibility in spending the budget according to school priority needs [27]. This generally illustrates that there is a policy to provide full discretion for schools or based on the main principles of School Based Budgeting.

\section{CONCLUSION AND RECOMMENDATIONS}

From the results of the research and discussion above, it can be concluded that the school-based budgeting approach is a strategy that can be used for Head Principals of SMA / SMK Negeri in funding the implementation of educational services during the Covid-19 period. During a pandemic like today, a high degree of flexibility is needed in the use of budgets, especially in schools. At the same time, the implementation of budget efficiency implemented by the government has resulted in reduced funding for schools. To respond to this, other sources of funding outside the government are needed, one of them is through donations. To convince the parents of students, an accurate program plan is needed and the ability to deliver the program to donors, so that donations can be raised properly. School Based- Budgeting is one of the solutions in financing education in schools during the Covid-19 pandemic. 
Recommendations obtained from this research include for the Government that the publication of regulations to provide flexibility for schools in funding educational services is deemed appropriate, for schools, of course, more efforts are needed outside of collecting contributions from parents of students, there are other sources that have not been explored optimally. Including from the world of business and industry, alumni, and the community around the school, in addition, it is necessary to formulate a truly mature program so that schools can convince donors to make donations.

However, further research is highly recommended in order to examine more deeply the influence of School BasedBudgeting on the effectiveness of school financing, especially in times of crisis such as the current Covid-19 pandemic.

\section{ACKNOWLEDGMENT}

This paper is presented for the 4th International Conference on Research of Educational Administration and Management (ICREAM) 2020

\section{REFERENCES}

[1] WHO, Novel Coronavirus(2019-nCoV) Situation Report - 10; 2020

[2] K. Azzi-Huch, and T. Shmis, "Managing the impact of COVID-19 on education systems around the world: How countries are preparing, coping, and planning for recovery", World Bank, Washington, D.C., 18 March 2020, [online]. Retrieved from https://blogs.worldbank.org/education/managing-impact-Covid-19 education-systems-around-world-howcountries-are-preparing

[3] Fay and Jacob, "Schools During the COVID-19 Pandemic: Sites and Sources of Community Resilience. Edmond J," Safra Center For Ethics; 2020

[4] Surat Edaran Menteri Pendidikan dan Kebudayaan Republik Indonesia Nomor 4 Tahun 2020 tentang Pelaksanaan Kebijakan Pendidikan dalam Masa Darurat Penyebaran Covid-19.

[5] Badan Pusat Statistik Republik Indonesia, Susenas; 2018.

[6] Badan Pusat Statistik Republik Indonesia. Provinsi Jawa Barat Dalam Angka; 2020

[7] Keputusan Gubernur Jawa Barat Nomor 189 Tahun 2020.

[8] Peraturan Gubernur Jawa Barat nomor 43 tahun 2020 tentang petunjuk teknis pemberian biaya operasional Pendidikan daerah pada SMA, SMK, SLB Negeri di Daerah Provinsi Jawa Barat.
[9] Undang-Undang Nomor 20 Tahun 2003 Tentang Sistem Pendidikan Nasional.

[10] Peraturan Pemerintah Nomor 48 Tahun 2008 Tentang Pendanaan Pendidikan

[11] Kementerian Keuangan Republik Indonesia, Informasi Anggaran Pendapatan dan Belanja Negarai Republik Indonesia; 2018

[12] Peraturan Pemerintah Nomor 19 Tahun 2005 tentang Standar Nasional Pendidikan.

[13] B. Subarna, Pendidikan Gratis Sekolah Menengah Pertama: Antara Harapan dan Kenyataan. Yogyakarta: Deepublish, 2014.

[14] A. Maretsya, and H.E. Soegiarto K, "Analisis strategi pembiayaan (finance) dalam upaya merebut pangsa," Ekonomia, vol. 4, no. 2, pp. 185-191, 2015.

[15] D.A. Kurniady, "Pengelolaan Pembiayaan Sekolah Dasar Di Kabupaten Bandung," Jurnal Penelitian Pendidikan, vol. 12, no. 1 p. 34, 2011.

[16] W.P. Ferdi, "Pembiayaan Pendidikan: Suatu Kajian Teoritis," Jurnal Pendidikan dan Kebudayaan, vol. 19, no. 4, pp. 565-578, 2013.

[17] O.D. Apuke, "Quantitative Research Methods A Synopsis Approach," vol. 6 , no. 10 , pp. 40-47, 2017

[18] Curristine. "Budgeting in a Crisis: Guidance for Preparing the 2021 Budget," International Monnetary Fund, 2020.

[19] UNICEF, "Covid-19 and Children in Indonesia An Agenda for Action to Address Challenges beyond Public Health An Agenda for Action to Address Socio-Economic Challenges," 2020

[20] World Bank Group Education, "The Covid-19 Pandemic: Shocks to Education and Policy Responses," 2020.

[21] A. Albright, "Global Partnership for Education," [online]. Retrieved from https://www.globalpartnership.org/blog/financing-our-future-3ways-protect-education-spending-impacts-covid-19; June 02, 2020 by

[22] Kementerian Keuangan Republik Indonesia, "pandemi-covid-19 mengajarkan-efisiensi-menuju-reformasi-struktural," [online]. Retrieved from https://www.kemenkeu.go.id/publikasi/berita/pandemi-covid-19mengajarkan-efisiensi-menuju-reformasi-struktural/; 2020.

[23] Rennie Center for Education Research \& Policy, Smart School Budgeting: Resources for Districts. Cambridge, MA: Rennie Center for Education Research \& Policy, 2012.

[24] L. Chan, School-Based Budgeting: A Cost-Benefit Model. United States: ERIC, 1997

[25] Peraturan Menteri Pendidikan dan Kebudayaan nomor 75 tahun 2016 tentang Komite Sekolah

[26] E. Mulyasa. Menjadi Kepala Sekolah yang Profesional. Bandung: PT Remaja Rosda Karya, 2007.

[27] Peraturan Menteri Pendidikan dan Kebudayaan Republik Indonesia Nomor 19 Tahun 2020 Tentang Perubahan atas Peraturan Menter Pendidikan dan Kebudayaan Nomor 8 Tahun 2020 tentang Petunjuk Teknis Bantuan Operasional Sekolah Reguler. 